\title{
RECOVERY OF SOIL MICROBIOLOGICAL PROPERTIES IN A DEGRADED AREA PLANTED WITH Corymbia Citriodora AND Leucaena Leucocephala
}

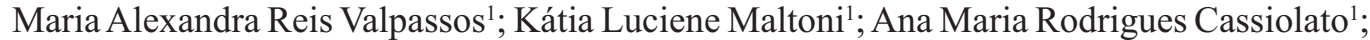 \\ Ely Nahas ${ }^{2 *}$ \\ ${ }^{I}$ UNESP/FEIS, Av. Brasil, 56 - 15385-000 - Ilha Solteira, SP - Brasil. \\ ${ }^{2}$ UNESP/FCAV, Rod. Prof. Paulo Donato Castellane, s/n - 14884-900 - Jaboticabal, SP - Brasil \\ *Corresponding author <enahas@fcav.unesp.br>
}

\begin{abstract}
The influence of reforestation was evaluated during two season periods (February and October) in sites planted with Corymbia citriodora and Leucaena leucocephala through microorganism counts (bacteria, fungi, actinomycetes, and nitrite oxidizers) and microbial activity (respiratory and urease activities). An Atlantic forest and a bare soil site were used as controls. The general trends of the variables in the different soils were: Atlantic forest or L. leucocephala $>C$. citriodora $>$ bare soil. The microbial populations in L. leucocephala and $C$. citriodora soils were significantly higher $(P<0.05)$ than that found in the bare soil. Similar results were obtained for respiratory and urease activities. The microbiological variables of the soil under L. leucocephala were comparable or even superior to that found under Atlantic forest. An improvement in the microbiological soil variables was observed in the soil under C. citriodora when compared to the soil without vegetation. These results can be attributed to an increasing amount of total organic $\mathrm{C}$ of the soils under L. leucocephala and C. citriodora in relation to the soil without vegetation. Although most results obtained in February presented higher values than in October, the sampling period did not have a consistent controlling influence on these variables.

Key words: bacteria, fungi, forest degradation, respiratory activity, urease
\end{abstract}

\section{RECUPERAÇÃO DAS PROPRIEDADES MICROBIOLÓGICAS DO SOLO EM UMA ÁREA DEGRADADA PLANTADA COM Corymbia Citriodora E Leucaena Leucocephala}

\begin{abstract}
RESUMO: O efeito do reflorestamento na qualidade do solo plantado com Corymbia citriodora e Leucaena leucocephala foi avaliado em duas épocas (fevereiro e outubro) através das contagens de microrganismos (bactérias, fungos, actinomicetos e oxidantes de nitrito) e da atividade microbiana (atividade respiratória e da urease). A Floresta Atlântica e uma área sem vegetação foram usadas como controle. A tendência geral das variáveis estudadas nos diferentes solos foi a seguinte: Floresta Atlântica ou L. leucocephala > C. citriodora $>$ sem vegetação. As populações microbianas nos solos de L. leucocephala e C. citriodora foram significativamente maiores $(P>0,05)$ do que as encontradas no solo sem vegetação. Resultados semelhantes foram obtidos para a atividade respiratória e da urease. As variáveis microbiológicas do solo sob L. leucocephala foram comparáveis ou até mesmo superiores às encontradas no solo sob Floresta Atlântica. Aumento das variáveis microbiológicas do solo sob C. citriodora foi observado quando comparado com o solo sem vegetação. Estes resultados podem ser atribuídos ao aumento nas quantidades de C orgânico total dos solos sob L. leucocephala e C. citriodora em relação ao solo sem vegetação. Embora a maioria dos resultados tenham sido maiores em fevereiro do que em outubro, não foi encontrada uma influência consistente do período de amostragem sobre as variáveis estudadas.

Palavras-chave: bactérias, fungos, degradação de florestas, atividade respiratória, urease
\end{abstract}

\section{INTRODUCTION}

In 1960, before the construction of the "Ilha Solteira" Hydroelectric Plant, $674 \mathrm{~km}^{2}$ of the Atlantic Forest were deforested. As a consequence, thousands of hectares were flooded and soils were degraded in vast areas due to compaction or the removal of $\mathrm{A} / \mathrm{B}$ horizons that exposed the subsoil. The reforestation of degraded areas contributes to restoring original soil physico-chemical characteristics by increasing the organic matter content, nutrient availability and the microbial populations and activity (Jha et al., 1992). Plant species is an important factor influencing the soil $\mathrm{C}$ and $\mathrm{N}$ content. Thus, while total $\mathrm{C}$ content was un- 
changed in an area in Hawaii reforested with Eucalyptus saligna (Binkley \& Resh, 1999), organic C increased under three of the eleven species planted in Costa Rica (Fisher, 1995). $\mathrm{N}_{2}$-fixing plants contribute to the soil $\mathrm{N}$ enrichment accumulating more $\mathrm{C}$ than the soils under non- $\mathrm{N}_{2}$-fixing species (Resh et al., 2002).

Soil bacteria and fungi are the main agents of biogeochemical transformations (Gallardo \& Schlesinger, 1994). Organic C is one of the main factors influencing the number, composition and activities of microbial communities (Wardle, 1992). In coniferous forest soil, while bacteria increased with soil fertility, fungi decreased (Pennanen et al., 1999). Organic $\mathrm{N}$ is converted to ammonium by the soil heterotrophic microoganisms and to nitrate $\left(\mathrm{NO}_{3}^{-}\right)$by the autotrophic nitrifiers. The number of autotrophic nitrifiers varies with the crop species and may be dependent on the fertilizer availability in the soil (Hanson et al., 2002).

The influence of environmental factors, crop management and organic substances on soil microbial communities can be evaluated examining microbial enzymatic and respiratory activity (Dilly \& Munch, 1996; Saviozzi et al., 2001). However, there is little information on the microbial activity in reforested soils. The objective of this research was to study the recovery of a degraded area (without vegetation) reforested with $C$. citriodora and L. leucocephala, evaluating the microbial communities and activities. For comparison, an Atlantic forest located nearby was also sampled.

\section{MATERIAL AND METHODS}

By the end of the 1960s, after a huge hydroelectric plant was constructed, part of the Atlantic Forest was eliminated and about $8 \mathrm{~m}$ (in depth) of soil were removed from the regolith. The site was partially reforested with Corymbia citriodora, in 1989, and with Leucaena leucocephala, in 1991. Two sites were used as controls: one where $8 \mathrm{~m}$ soil was removed and has been without vegetation since 1969 , and the other within an Atlantic forest. The sites $\left(51^{\circ} 20^{\prime} \mathrm{W} ; 20^{\circ} 23^{\prime}\right.$ $\mathrm{S})$ are located in Ilha Solteira, SP, Brazil. The $C$. citriodora, L. leucocephala and bare soil were classified (FAO-Unesco) as Ferralsols, and the Atlantic forest as Acrisol, with a clay-sandy texture. The amounts of rainfall were $368 \mathrm{~mm}$ in February 2000 and $138 \mathrm{~mm}$ in October 2000. Soil samples were randomly collected from each site in February and October 2000 at the 0 $-10 \mathrm{~cm}$ depth.

Most probable number (MPN) counts were determined using nutrient agar, Martin medium (Martin, 1950 ) and glucose-asparagine (Kuster \& Williams, 1964) for bacteria, fungi and actinomycetes, respec- tively. The MPN count of microorganisms was determined on soil samples using a 10 -fold serial dilution, followed by inoculation of five drops $(40 \mathrm{~mL})$ from each dilution onto the surface of the appropriate nutrient agar plate (Carvalhal et al., 1991). Each plate contained 15 drops for each of the three dilutions. After a 48-hour-incubation for bacteria and fungi and a 21-day-incubation for the actinomycetes all at $27^{\circ} \mathrm{C}$, the microbial growth was observed by microscope under 40-fold magnification. For the nitrite oxidizer counts, $1 \mathrm{~mL}$ of each soil dilution was added to $4 \mathrm{~mL}$ of culture medium (Schmidt \& Belser, 1982), and incubated at $27^{\circ} \mathrm{C}$. After eight week-incubation, positive results were observed in the medium by color change.

Soil respiration was determined by incubating $100 \mathrm{~g}$ (wet weight) soil in $800 \mathrm{~mL}$ containers at $27^{\circ} \mathrm{C}$ for four days. Evolved $\mathrm{CO}_{2}$ was trapped in the $0.1 \mathrm{~mol}$ $\mathrm{L}^{-1} \mathrm{NaOH}$ solution and determined by titration with 0.1 mol L $\mathrm{L}^{-1} \mathrm{HCl}$. The urease activity was determined using the method described by McGarity \& Myers (1967). One enzyme activity unit corresponded to the enzyme quantity to hydrolyze $1 \mathrm{Pg}$ urea $/ 3 \mathrm{~h}$ at $37^{\circ} \mathrm{C}$. The specific activity was expressed in $\mathrm{Pg} \mathrm{NH}_{4}{ }^{+} \mathrm{N} \mathrm{g}^{-1}$ dry soil.

The soil organic $\mathrm{C}$ was determined by the oxidation method using potassium dichromate-sulfuric acid (Sims \& Haby, 1971). Polysaccharides were quantified by soil extracts obtained with $\mathrm{NaOH}$ solution and oxidation with dichromate (Stevenson, 1982). Soil chemical composition was determined according Van Raij \& Quaggio (1993) (Table 1).

The data were analyzed by one way analysis of variance to test for significant differences between treatments using the SAS GLM procedure. Each treatment consisted of ten replicates. Means were compared by the Duncan multiple range test $(P<0.05)$. The microbial count values were transformed as $\log (\mathrm{x}+1)$, where $\mathrm{x}=\mathrm{MPN} \mathrm{g}^{-1}$ dry soil, before statistical analysis. Correlation analyses (r) were made between selected variables.

\section{RESULTS AND DISCUSSION}

The influence of the reforestation and soilsampling period on the total bacteria, fungi, actinomycetes and nitrite oxidizers bacteria counts are presented in Table 2. Overall, the number of the microorganisms under the Atlantic forest, Leucaena and Corymbia soils were higher $(P<0.05)$ than under the bare soil. The combined effect of vegetation type and organic matter degradation presumably explains the higher microorganism number in these soils when compared to the bare soil. 
There was a considerable (375- to 393-fold) increase of the bacterial populations in the Atlantic forest and Leucaena soils as compared to the bare soil. Similarly, the fungi counts had a 245 -fold and 10 -fold increase, respectively, in those soils. Also, bacteria and fungi counts were approximately four times higher in the soil under Corymbia than under bare soil. Bacteria number were dependent on the total organic $\mathrm{C}$ and $\mathrm{N}$ concentrations (Morris \& Boerner, 1998). This effect was evident by the positive correlation between total organic $\mathrm{C}$ concentrations and the number of bacteria $(\mathrm{r}=0.80 * * *)$, fungi $\left(\mathrm{r}=0.63^{* * *}\right)$ and actinomycetes $\left(\mathrm{r}=0.59^{* * *}\right)$ (Table 3). The populations of microorganisms found in the Leucaena soil were generally similar to the Atlantic forest soil and higher than in the Corymbia soil. These results were probably due to a synergistic action of the Leucaena $\mathrm{N}_{2}$ fixation and its potential ability in improving soil fertility (Table 1 ) because le- gume species as Prosopis spp. and Acacia tortuosa accumulate more organic matter, nutrients and microorganisms in the soil than do non-leguminous species (Reyes-Reyes et al., 2002).

The number of actinomycetes were very low

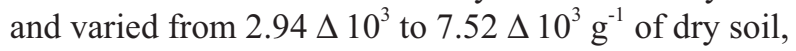
respectively (Table 2). The Leucaena soil had the highest actinomycete count. The influence of the vegetations on nitrite oxidizers was similar to that observed for soil bacteria and fungi as follows: Atlantic forest $>$ Leucaena $>$ Corymbia $>$ bare soil. Meanwhile the fungal populations were generally higher $(P<0.05)$ in February than in October, the number of actinomycetes and nitrite oxidizers were higher in October than in February (Table 2). The bacteria number increased in February as compared to October in the soils under Corymbia and bare soil. In the soils under Atlantic forest and Leucaena, the bacteria number was higher in October.

Table 1 - Effect of reforestation on chemical properties of the soils.

\begin{tabular}{|c|c|c|c|c|c|c|c|c|}
\hline Vegetation/Soil & $\mathrm{pH}$ & $\mathrm{P}$ & Organic matter & $\mathrm{K}^{+}$ & $\mathrm{Ca}^{2+}$ & $\mathrm{Mg}^{2+}$ & $\mathrm{H}^{+}+\mathrm{Al}^{3+}$ & $\mathrm{CEC}$ \\
\hline & $\mathrm{Cacl}^{2} 0.01 \mathrm{~mol} \mathrm{~L}^{-1}$ & $\mathrm{mg} \mathrm{dm}{ }^{-3}$ & $\mathrm{~g} \mathrm{dm}^{-3}$ & \multicolumn{5}{|c|}{ - mmol $\mathrm{dm}^{-3}-\mathrm{m}_{\mathrm{c}}$} \\
\hline Atlantic forest & 4.6 & 4.9 & 30.3 & 1.3 & 25.3 & 6.2 & 35.7 & 68.3 \\
\hline Leucaena & 4.1 & 7.4 & 32.9 & 1.3 & 8.9 & 4.2 & 59.8 & 74.0 \\
\hline Corymbia & 3.9 & 2.9 & 14.6 & 2.1 & 8.6 & 2.6 & 26.9 & 40.1 \\
\hline Bare soil & 4.2 & 1.1 & 9.4 & 1.3 & 6.7 & 2.0 & 20.4 & 30.4 \\
\hline
\end{tabular}

Table 2 - Effect of the reforestation and sampling periods on microorganisms counts.

\begin{tabular}{|c|c|c|c|c|c|c|c|c|}
\hline \multirow{2}{*}{$\begin{array}{l}\text { Micro- } \\
\text { organisms }\end{array}$} & \multicolumn{2}{|c|}{ Atlantic Forest } & \multicolumn{2}{|c|}{ Leucaena } & \multicolumn{2}{|c|}{ Corymbia } & \multicolumn{2}{|c|}{ Bare soil } \\
\hline & February & October & February & October & February & October & February & October \\
\hline & - & - & & $-\ldots N^{0} u$ & $\mathrm{~g}^{-1}$ dry so & . & & (n- \\
\hline Bacteria & $11.17 \mathrm{aB}$ & $13.80 \mathrm{aA}$ & $11.03 \mathrm{aB}$ & $13.86 \mathrm{aA}$ & $9.06 \mathrm{bA}$ & $7.82 \mathrm{bB}$ & $7.65 \mathrm{cA}$ & $6.58 \mathrm{cB}$ \\
\hline Fungi & $12.39 \mathrm{aA}$ & $11.03 \mathrm{aB}$ & $8.92 \mathrm{bA}$ & $8.56 \mathrm{bB}$ & $8.30 \mathrm{cA}$ & $7.02 \mathrm{cB}$ & $6.51 \mathrm{dA}$ & $6.41 \mathrm{cA}$ \\
\hline Actinomycetes & $5.03 \mathrm{cB}$ & $7.14 \mathrm{bA}$ & $6.53 \mathrm{aB}$ & $7.52 \mathrm{aA}$ & $5.89 \mathrm{bB}$ & $6.34 \mathrm{cA}$ & $2.94 \mathrm{~dB}$ & $6.12 \mathrm{cA}$ \\
\hline $\mathrm{NO}_{2}^{-}$oxidizers & $7.42 \mathrm{bB}$ & $11.74 \mathrm{aA}$ & $8.98 \mathrm{aB}$ & $10.93 \mathrm{aA}$ & ND & $8.36 \mathrm{bA}$ & $3.05 \mathrm{cB}$ & $3.96 \mathrm{cA}$ \\
\hline
\end{tabular}

Different lower-case letters or upper-case letters indicate differences between vegetations types (in the same period) or sampling periods, respectively, according to an LSD value $(P<0.05)$. ND, no detected.

Table 3 - Correlation between MPN counts, soil microbial activities and selected variables.

\begin{tabular}{|c|c|c|c|c|c|c|c|}
\hline Variable & Fungi & Actin. & $\mathrm{NO}_{2}^{-} \mathrm{Ox}$ & $\mathrm{OC}$ & $\mathrm{C}-\mathrm{CO}_{2}$ & Polys. & Urease \\
\hline Bacteria & $0.57 * * *$ & $0.45 * * *$ & $0.67 * * *$ & $0.80 * * *$ & $0.79 * * *$ & $-0.01 \mathrm{NS}$ & $0.75 * * *$ \\
\hline Fungi & - & $0.12 \mathrm{NS}$ & $0.37 * * *$ & $0.63 * * *$ & $0.62 * * *$ & $0.30 * *$ & $0.64 * * *$ \\
\hline Actinomycetes & - & - & $0.58 * * *$ & $0.59 * * *$ & $0.62 * * *$ & $0.55 * * *$ & $0.41 * * *$ \\
\hline $\mathrm{NO}_{2}^{-}$oxidizers & - & - & - & $0.69 * * *$ & $0.78 * * *$ & $-0.43 * * *$ & $0.67 * * *$ \\
\hline Organic C & - & - & - & - & $0.91 * * *$ & $0.01 \mathrm{NS}$ & $0.82 * * *$ \\
\hline $\mathrm{CO}_{2}{ }_{2}^{-\mathrm{C}}$ & - & - & - & - & - & $-0.14 \mathrm{NS}$ & $0.79 * * *$ \\
\hline Polysaccharides & - & - & - & - & - & - & $0.02 \mathrm{NS}$ \\
\hline
\end{tabular}

***Significant $(P<0.001)$; NS - Not Significant; Actin., Actinomycetes; $\mathrm{NO}_{2}^{-} \mathrm{Ox}, \mathrm{NO}_{2}^{-}$oxidizers; OC, Organic C; Polys., Polysaccharides. 
Higher nitrite oxidizer numbers were found in soils under Atlantic forest, Corymbia and Leucaena as compared to the soil without vegetation. The nitrite oxidizers number was positively correlated with total organic $\mathrm{C}\left(\mathrm{r}=0.69^{* * *}\right)$ and negatively correlated with the polysaccharide concentration $\left(\mathrm{r}=-0.43^{* * *}\right)$. Nitrite oxidizers do not depend on a carbon source to grow, however depend on the organic N-compound ammonification by the heterotrophic microorganisms. In addition, although quite low, the positive correlation found between the nitrite oxidizers and bacteria $\left(\mathrm{r}=0.67^{* * *}\right)$, fungi $\left(\mathrm{r}=0.37^{* * *}\right)$ and actinomycetes $\left(\mathrm{r}=0.58^{* * *}\right)$ counts confirmed this relationship. Correlations between these microorganism groups, except for fungi, were also observed by Acea \& Carballas (1990).

Total organic C (Figure 1A) and polysaccharide contents (Figure 1B) were higher $(P<0.05)$ in the Atlantic forest and Leucaena soils than in the Corymbia and bare soils. Total organic $\mathrm{C}$ and polysaccharide contents found in February were higher than in October. However, total organic C contents were lower in February in the Leucaena and bare soils, and were similar in both periods for the soils under Atlantic forest and Corymbia (Figure 1).

The respiratory and urease activities decreased according to the following trend: Atlantic forest or Leucaena $>$ Corymbia $>$ bare soil (Figure 2). The urease activities found in October were similar between the soils under Atlantic forest and Leucaena but higher
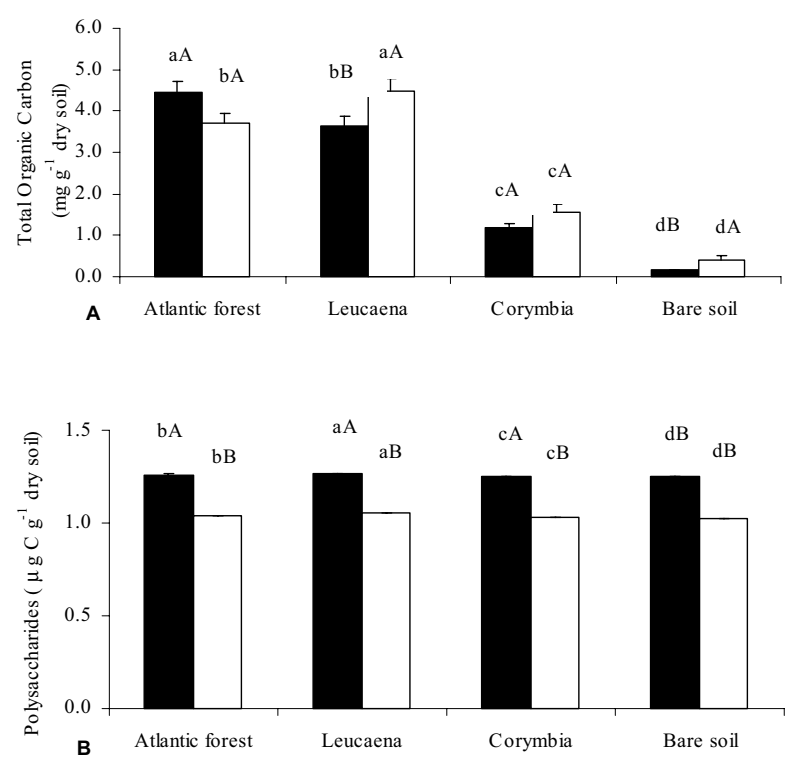

Figure 1 - Effect of reforestation on total organic $\mathrm{C}$ and polysaccharides. Different lower case letters or upper case letters above the bars indicate significant differences between vegetation types or sampling periods, respectively, according to an LSD value $(P<0.05)$. Bars represent standard errors of the mean. ( $\square$ ), February; $\square$ ), October.
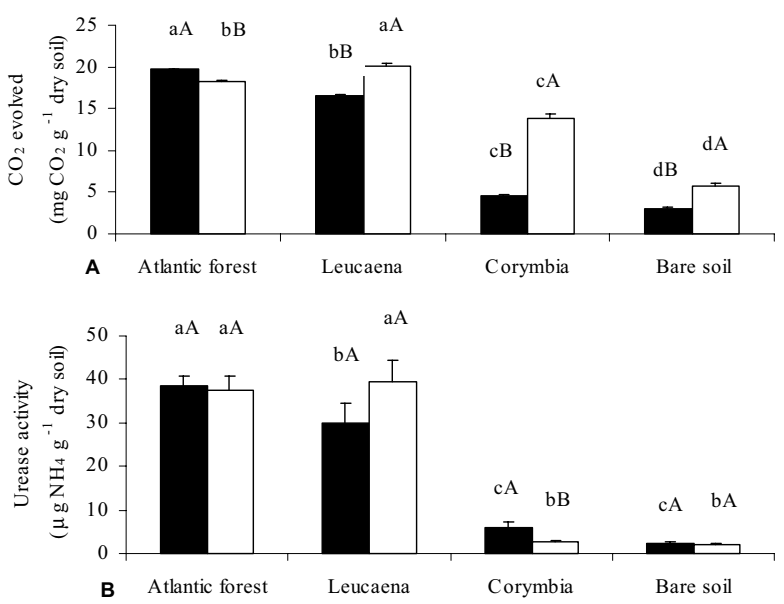

Figure 2 - Effect of reforestation on respiratory and urease activities. Different lower case letters or upper case letters above the bars indicate significant differences between vegetations or sampling period, respectively, according to an $\mathrm{LSD}$ value $(P<0.05)$. Bars represent standard errors of the mean. ( $\square$ ), February; $(\square)$, October.

than the activities found in the Corymbia and bare soils. The respiratory activity was lower $(P<0.05)$ in February than October, except for the Atlantic forest soil (Figure 2A), and the urease activity was similar in both periods, except for the Corymbia soil (Figure 2B). Microbial respiratory activity is an indication of carbon utilization efficiency (Saviozzi et al., 2001). The increasing respiratory activity may probably be attributed to an increase of both bacteria $(\mathrm{r}=0.79 * * *)$, fungal $(\mathrm{r}=0.62 * * *)$, and actinomycete $\left(\mathrm{r}=0.59^{* * *}\right)$ populations. The soil $\mathrm{C}$ concentration under different vegetation management systems influenced respiratory activity (Kaur et al., 2000). Also, a positive correlation between soluble organic $\mathrm{C}$ content and respiratory activity was similarly reported (Arunachalam et al., 1999). In agreement with these authors, a high positive correlation was found in the present study between the total organic $\mathrm{C}$ content and the respiratory activity $(\mathrm{r}=0.91$ ***). The highest organic $\mathrm{C}$ values were found in the soils under Atlantic forest and Leucaena (Figure 1) and corresponded to the highest respiratory activities.

The urease activity was higher in the Atlantic forest and Leucaena soils as compared to the Corymbia or bare soils. In general, a significant variation has been observed in the urease activity dependent on the soil vegetation type (Bandick \& Dick, 1999; Waldrop et al., 2000). A higher urease activity in less degraded areas than in more degraded sites, due to the higher soil organic $\mathrm{C}$ contents and microbial populations sizes was found (Jha et al., 1992). Accordingly, in the present study, there was a positive correlation between urease activity and microorganism populations or to- 
tal organic C. Similarly, a positive correlation between the urease activity and the organic $\mathrm{C}$ was found (Singh et al., 1991).

Soil moisture had greater influence than temperature on soil microbial populations (Acea \& Carballas, 1990). In soils under Eucalyptus and Pinus, the total number of bacteria and respiratory and dehydrogenase activities were higher during summer, because of the higher rainfall and air temperatures (Rigobelo \& Nahas, 2004). Variations in climatic factors, litterfall and soil chemical attributes have a greater influence on $\mathrm{CO}_{2}$ production and cellulase activity during autumn and spring than during summer and winter (Vardavakis, 1989). Our results demonstrated no consistent influence of the sampling period on these variables. The air temperatures were similar in both months; however, precipitation in February (summer) was almost 3-fold higher than in October (spring) (138 $\mathrm{mm}$ ), which might not be enough for a limiting factor to affect these variables. Similarly, differences in ergosterol concentrations between summer and spring samplings were not found, due to a too small difference in soil temperature and humidity during those periods (Imberger \& Chiu, 2002). In this way, other factors such as the amount of litterfall, organic matter mineralization and soil nutrient contents might be related to the seasonal climatic variations (Imberger \& Chiu, 2002; Rigobelo \& Nahas, 2004).

\section{ACKNOWLEDGMENTS}

To FAPESP for financial support and to CNPq for the fellowships to M.A.R. Valpassos and E. Nahas.

\section{REFERENCES}

ACEA, M. J.; CARBALLAS, T. Principal components analysis of the soil microbial population of humid zone of Galicia (Spain). Soil Biology \& Biochemistry, v.22, p.749-759, 1990.

ARUNACHALAM, K.; ARUNACHALAM, A.; MELKANIA, N.P. Influence of soil properties on microbial populations, activity and biomass in humid subtropical mountainous ecosystems of India. Biology and Fertility of Soils, v.30, p.217-223, 1999

BANDICK, A.K.; DICK, R.P. Field management effects on soil enzyme activities. Soil Biology \& Biochemistry, v.31, p.1471-1479, 1999.

BINKLEY, D.; RESH, S.C. Rapid changes in soils following Eucalyptus afforestation in Hawaii. Soil Science Society of America Journal, v.63, p.222-225, 1999.

CARVALHAL, M.L.C.; OLIVEIRA, M.S.; ALTERTHUM, F. An economical and time saving alternative to the most-probable-number method for the enumeration of microorganisms. Journal of Microbiological Methods, v.14, p.165-170, 1991.

DILLY, O.; MUNCH, J.C. Microbial biomass content, basal respiration and enzyme activities during the course of decomposition of leaf litter in a black alder (Alnus glutinosa (L.) Gaertn.) forest. Soil Biology and Biochemistry, v.28, p.1073-1081, 1996.

FISHER, R.F. Amelioration of degraded rain forest soils by plantation of native trees. Soil Science Society of America Journal, v.59, p.544-549, 1995
GALLARDO, A.; SCHLESINGER, W.H. Factors limiting microbial biomass in the mineral soil and forest floor of a warm-temperate forest. Soil Biology \& Biochemistry, v.26, p.1409-1415, 1994.

HANSON, E.J.; THROOP, P.A.; SERCE, S.; RAVENSCROFT, J.; PAUL, E.A. Comparison of nitrification rates in blueberry and forest soils. Journal of the American Society for Horticultural Science, v.127, p.136-142, 2002.

IMBERGER, K.T.; CHIU, C.Y. Topographical and seasonal effects on soil fungal and bacterial activity in subtropical, perhumid, primary and regenerated montane forests. Soil Biology \& Biochemistry, v.34, p.711720, 2002.

JHA, D.K.; SHARMA, G.D.; MISHRA, R.R. Soil microbial population numbers and enzyme activities in relation to altitude and forest degradation Soil Biology \& Biochemistry, v.24, p.761-767, 1992.

KAUR, B.; GUPTA, S.R.; SINGH, G. Soil carbon, microbial activity and nitrogen availability in agroforestry systems on moderately alkaline soils in northern India. Applied Soil Ecology, v.15, p.283-294, 2000.

KUSTER, E.; WILLIAMS, S.T. Selection of media for isolation of Streptomycetes. Nature, v.202, p.928-929, 1964.

MARTIN, J.P. Use of acid, rose bengal, and streptomycin in the plate method for estimating soil fungi. Soil Science, v.69, p.215 232, 1950.

McGARITY, J.W.; MYERS, M.G. A survey of urease activity in soils of Northern New South Wales. Plant and Soil, v.27, p.217-238, 1967.

MORRIS, S.J.; BOERNER, R.E.J. Interactive influences of silvicultural management and soil chemistry upon soil microbial abundance and nitrogen mineralization. Forest Ecology and Management, v.103, p.129-139, 1998

PENNANEN, T.; LISKI, J.; BÁÁTH, E.; KITUNEN, V.; UOTILA, J.; WESTMAN, C.J.; FRITZE, H. Structure of the microbial communities in coniferous forest soils in relation to site fertility and stand development stage. Microbial Ecology, v.38, p.168-1799, 1999.

RESH, S.C.; BINKLEY, D.; PARROTTA, J.A. Greater soil carbon sequestration under nitrogen-fixing trees compared with Eucalyptus species. Ecosystems, v.5, p.217-231, 2002.

REYES-REYES, G.; BARON-OCAMPO, L.; CUALI-ALVAREZ, I.; FRIAS-HERNANDEZ, J.T.; OLALDE-PORTUGAL, V.; VARELAFREGOSO, L.; DENDOOVEN, L. C and N dynamics in soil from the central highlands of Mexico as affected by mesquite (Prosopis spp.) and huizache (Acacia tortuoso): A laboratory investigation. Applied Soil Ecology, v.19, p.27-34, 2002.

RIGOBELO, E.C.; NAHAS, E. Seasonal fluctuations of bacterial population and microbial activity in soils cultivated with Eucalyptus and Pinus. Scientia Agricola, v.61, p.88-93, 2004.

SAVIOZZI, A.; LEVI-MINZI, R.; CARDELLI, R.; RIFFALDI, R. A comparison of soil quality in adjacent cultivated, forest and native grassland soils. Plant and Soil, v. 233, p.251-259, 2001.

SCHMIDT, E.L.; BELSER, L.W. Nitrifying bacteria. In: PAGE, A.L.; MILLER, R.H.; KEENEY, D.R. (Ed.). Methods of soil analysis: Part 2. Chemical and microbiological properties. Madison: ASA, 1982. p. 1027-1042.

SIMS, J.R.; HABY, V.A. Simplified colorimetric determination of soil organic matter. Soil Science, v.112, p.137-141, 1971.

SINGH, J.P.; KUMAR, V.; DAHIYA, D.J. Urease activity in some benchnmark soils of Haryana and its relationship with various soil properties. Journal of the Indian Society of Soil Science, v.39, p.281-285, 1991.

STEVENSON, F.J. Humus chemistry: genesis, composition, reactions. New York: John Wiley, 1982. 443p.

VAN RAIJ, B.V.; QUAGGIO, J.A. Métodos de análises de solos para fins de fertilidade. Campinas: Instituto Agronômico, 1993. 31p.

VARDAVAKIS, E. Seasonal fluctuations of aerobic cellulolytic bacteria, and cellulase and respiratory activities in a soil profile under a forest. Plant and Soil, v.115, p.145-150, 1989.

WALDROP, M.P.; BALSER, T.C; FIRESTONE, M.K. Linking microbial community composition to function in a tropical soil. Soil Biology \& Biochemistry, v.32, p.1837-1846, 2000.

WARDLE, D.A. A comparative assessment of factors which influence microbial biomass carbon and nitrogen levels in soils. Biological Reviews, v.67, p.321-358, 1992.

Received February 17, 2006

Accepted January 16, 2007 